\title{
Predictors of COVID-19 Positivity in Ndokwa-West District in Nigeria. A retrospective Cohort Study
}

\author{
Agofure Otovwe ${ }^{1}$, Akanigha Towuaghantse Roli ${ }^{1}$, Ogbolu Christabel \\ Nneka $^{1}$, Okandeji-Barry Rume Oghenenioborue ${ }^{2}$, Chimsunum John ${ }^{3}$ \\ ${ }^{1}$ Department of Public and Community Health, Novena University Ogume, Delta State \\ Nigeria. \\ ${ }^{2}$ Department of Health Care, Waltham International College, United Kingdom \\ ${ }^{3}$ Disease Surveillance and Notification office, Ndokwa-West Local Government \\ Area of Delta State, Nigeria
}

Corresponding Author Agofure Otovwe.

Mobile:

$+23407030839248$

E mail: agofureotovwe@yahoo .com

Key words:

Covid-19 testing, Retrospective Studies, Comorbidity, Cough, Nausea, Logistic Regression, Nigeria
Background and study aim:Despite the increasing prevalence, morbidity, and mortality associated with Covid-19, there is paucity of data locally assessing independent factors such as demographic and clinical data predicting Covid-19 positivity. This study was designed to investigate the likely predictors of Covid19 positivity in Ndokwa-West Local Government Area of Delta State Nigeria.

Patients and Methods:A retrospective cohort study was conducted among 1133 individuals who undertook the RT-PCR Covid-19 test from April 2020 to August 2021 in Ndokwa-West Local Government Area of Delta State Nigeria. Both bivariate and multivariable logistic regression analyses were performed to identify independent predictors that are associated with Covid-19 positivity.

Results:A total of 1133 patients were tested for COVID-19, with 67 confirmed cases. Socio-demographic variables independently predicting Covid-19

\section{INTRODUCTION}

Coronavirus 2019 (Covid-19) is an infectious disease caused by the severe acute respiratory syndrome coronavirus 2 (SARS-CoV-2) [1,2]. The Covid-19, which was officially declared a global pandemic on 11 March 2020, has spread to all continents of the world. Globally, as at 13 October, 2021 there has been $238,521,855$ laboratories confirmed cases of COVID-19, including $4,863,818$ deaths while in Africa there has been 6,093,774 confirmed cases of Covid-19 [3]. As at 13 October, 2021 there has been 208,404 laboratory-confirmed cases of Covid- positivity were age (OR=188.0 95\% $\mathrm{CI}=17.011-2077.717)$, male sex $(\mathrm{OR}=1.623 \quad 95 \% \quad \mathrm{CI}=0.950-2.775)$, traveling in the last 14 days prior to the Covid-19 test $(\mathrm{OR}=1.76195 \% \mathrm{CI}=1.003$ 3.092) and the following presenting symptoms: cough $\quad(\mathrm{OR}=1.229 \quad 95 \%$ $\mathrm{CI}=0.865-2.706)$, shortness of breath $(\mathrm{OR}=23.202 \quad 95 \% \quad \mathrm{CI}=8.821-61.030)$, vomiting $\quad(\mathrm{OR}=2.211 \quad 95 \% \quad \mathrm{CI}=1.077$ 4.540), and nausea (OR=10.130 95\% $\mathrm{CI}=5.943-17.267)$. Others were comorbidity $\quad(\mathrm{OR}=2.048 \quad 95 \% \quad \mathrm{CI}=1.103$ 3.802), and other severe life threatening illnesses $\quad(\mathrm{OR}=1.994 \quad 95 \% \quad \mathrm{CI}=1.187$ 3.348).

Conclusion: The study highlighted the independent predictors of Covid-19 positivity, which was similar to the national level. This finding should guide health workers and policymakers at the local and national levels in implementing best Covid-19 testing and care practices.

19 in Nigeria, including 9,520 deaths while there have been 3,553 laboratory-confirmed cases of Covid19 in Delta State including 110 deaths [4].Currently, various literature on Covid-19 have reported various aspects of the disease, including the epidemiological profile, manifestations, outcomes, and factors independently predicting Covid-19 positivity and outcomes. A study in China assessed the clinical characteristics of Covid-19 [5], while a study on the clinical presentation, case management and outcomes for the first 32 patients with COVID-19 in Nigeria found that patients were 
predominantly male with a mean age of 38 years [6]. Similarly, a national study in Nigeria found the independent factors associated with Covid-19 positivity to be older age, male sex, cough, fever, loss of smell, and taste. In addition, increased risk of mortality was observed in patients aged $\geq 51$ years, those presenting with cough, breathing difficulties and vomiting [7]. Currently, there is a paucity of studies assessing factors predicting Covid-19 positivity in most districts or local governments in Nigeria. Assessing the factors would be pertinent for health workers, policymakers at the district or local government level and the general population considering the increase of Covid-19 related morbidity and mortality due to the presence of the mutated Delta and omicron variants.

Aim of the work: to investigate the likely predictors of Covid-19 positivity in NdokwaWest Local Government Area of Delta State Nigeria.

\section{PATIENTS AND METHODS}

Study Design: This retrospective cohort study involves the retrospective analysis of patients' data from April 2020 to August 2021.

Study Settings: The study was conducted in the Ndokwa-West Local Government Area of Delta State. Ndokwa-West is one of the local government areas of Delta North senatorial district and has its local government headquarters in Kwale.

Study Population: The study population comprised all individuals who were investigated for Covid-19 using real-time PCR (RT-PCR) testing and captured on the Surveillance, Outbreak, Response, Management and Analysis System (SORMAS) from April 2020 to August 2021 in Ndokwa-West Local Government Area of Delta State.

Sample Size and Sampling Procedure: All 1133 patients who presented for the Covid-19 test in Ndokwa-West Local Government Area from April 2020 to August 2021 were extracted, reviewed and purposively selected for the study.

Data Sources: The data was extracted from SORMAS. This is an electronic health surveillance database maintained by NCDC [8]. The SORMAS is domiciled in the Disease Surveillance and Notification office of the
Ndokwa-West Local Government Area of Delta State.

Data Collection: Samples were collected from individuals who met the eligibility criteria of RTPCR test of NCDC COVID-19 suspect case definition [9]. These samples were transported to Asaba the state capital where we have the nearest NCDC-certified laboratory for COVID-19 while maintaining a temperature range of $2^{\circ} \mathrm{C}-4^{\circ} \mathrm{C}$ in line with the WHO guidelines [10], and analysis were performed according to the NCDC guidelines for identifying and reporting suspected COVID-19 cases [11]. RT-PCR was used for the laboratory diagnosis of COVID-19. Laboratory results, pertinent patients' characteristics and clinical data were entered into the SORMAS by a designated public health officer at the Disease Surveillance and Notification office of the Ndokwa-West Local Government Area of Delta State.

Instrument for data collection: A designed proforma containing information on a number of individuals who were tested for Covid-19, sociodemographic characteristics, signs and symptoms, co-morbidity and other severe lifethreatening illnesses were used to extract the data. Data Analysis: The data was analysed using SPSS version 23.0 and qualitative data presented in frequency tables and percentages. Chi-square test $(\chi 2)$ were used in performing bivariate analysis for socio-demographic and clinical variables vs Number of patients that took the Covid-19 test which was either positive or negative. Those that were significant in the ChiSquare analysis were further subjected to multivariate analysis using logistic regression as predictors of Covid-19 positivity. All statistical comparisons were two-tailed with significance Level of $\mathrm{P}$-value $<0.05$ indicates significant while P> 0.05 indicates a Non-significant difference.

\section{RESULTS:}

\section{Prevalence of Covid-19}

According to figure 1, 67(5.9\%) of the patients tested positive for Covid-19, while 1066(94.1\%) tested negative for Covid-19.

Bivariate analysis in table 1 shows a significant association between ages of the patients $(\rho=0.000)$, sex $(\rho=0.034)$, occupation $(\rho=0.035)$ 
and travelling in the last 14 days before the covid-19 test ( $\rho=0.046)$ and Covid-19 positivity.

In table 2 multivariate analysis shows ages 56-65 years $(\mathrm{OR}=188.0,95 \% \mathrm{CI}=17.011-2077.717)$, $25-40$ years $(\mathrm{OR}=54.923, \quad 95 \% \quad \mathrm{CI}=5.338$ $565.064)$, and $41-55$ years $(\mathrm{OR}=36.240,95 \%$ $\mathrm{CI}=3.635-361.333)$ predicted Covid-19 positivity; while male sex $(\mathrm{OR}=1.623,95 \%$ $\mathrm{CI}=0.950-2.775)$ and travelling in the last 14 days prior to the taking the covid-19 test $(\mathrm{OR}=1.761$, 95\% CI=1.003-3.092) predicted Covid-19 positivity.

According to table 3, patients having comorbidity $(\rho=0.021)$, Cough $(\rho=0.000)$, shortness of breath $(\rho=0.000)$, nausea $(\rho=0.000)$ and other severe life-threatening illness $(\rho=0.008)$ all showed significant association with Covid-19 Positivity.

In table 4 , multivariate analysis shows that comorbidity $\quad(\mathrm{OR}=188.0, \quad 95 \% \quad \mathrm{CI}=17.011$ 2077.717), shortness of breath $(\mathrm{OR}=23.202,95 \%$ $\mathrm{CI}=8.821-61.030)$, vomiting $(\mathrm{OR}=2.211,95 \%$ $\mathrm{CI}=1.077-4.540)$, and having other life threatening illness $(\mathrm{OR}=1.994,95 \% \mathrm{CI}=1.187$ 3.348) significantly predicted Covid-19 positivity.

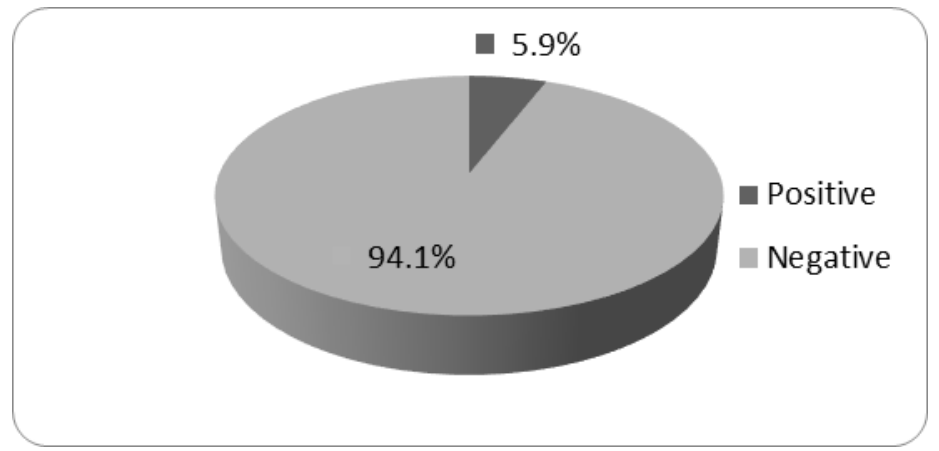

Figure (1): Prevalence of Covid-19

Table (1): Bivariate analysis of socio-demographic characteristics and Covid-19 Positivity.

\begin{tabular}{|c|c|c|c|c|c|}
\hline \multirow{2}{*}{ Variables } & \multicolumn{2}{|c|}{ No. of persons tested for covid-19 } & \multirow{2}{*}{$\mathrm{X}^{2}$} & \multirow{2}{*}{ df } & \multirow{2}{*}{ Sig. } \\
\hline & Positive & Negative & & & \\
\hline \begin{tabular}{|l} 
Age \\
$10-24$ \\
$25-40$ \\
$41-55$ \\
$56-65$ \\
$66-75$ \\
$76-95$ \\
\end{tabular} & $\begin{array}{c}3(0.3 \%) \\
13(1.1 \%) \\
25(2.2 \%) \\
6(0.5 \%) \\
13(1.1 \%) \\
7(0.6 \%) \\
\end{array}$ & $\begin{array}{c}1(0.1 \%) \\
238(21.0 \%) \\
302(26.7 \%) \\
376(33.2 \%) \\
116(10.2 \%) \\
33(2.9 \%) \\
\end{array}$ & 62.941 & 5 & 0.000 \\
\hline \begin{tabular}{|l} 
Sex \\
$\quad$ Male \\
Female \\
\end{tabular} & $\begin{array}{l}46(4.1 \%) \\
21(1.9 \%) \\
\end{array}$ & $\begin{array}{l}832(73.4 \%) \\
234(20.7 \%)\end{array}$ & 3.188 & 1 & 0.034 \\
\hline \begin{tabular}{|l|} 
Marital Status \\
Married \\
Single \\
\end{tabular} & $\begin{array}{r}65(5.7 \%) \\
2(0.2 \%) \\
\end{array}$ & $\begin{array}{c}979(86.4 \%) \\
87(7.7 \%) \\
\end{array}$ & 2.333 & 1 & 0.127 \\
\hline \begin{tabular}{|l|} 
Educational Status \\
Educated \\
Uneducated \\
\end{tabular} & $\begin{array}{c}67(5.9 \%) \\
0(0.0 \%)\end{array}$ & $\begin{array}{c}1059(92.8 \%) \\
7(0.6 \%) \\
\end{array}$ & 0.443 & 1 & 0.506 \\
\hline \begin{tabular}{|l|} 
Occupation \\
$\quad$ Civil Servant \\
Retired \\
Self Employed/Business \\
\end{tabular} & $\begin{array}{c}47(4.3 \%) \\
0(0.0 \%) \\
20(1.8 \%) \\
\end{array}$ & $\begin{array}{l}782(64.3 \%) \\
57(5.0 \%) \\
227(20.0 \%) \\
\end{array}$ & 5.788 & 2 & 0.035 \\
\hline $\begin{array}{l}\text { Travelled in the last } 14 \text { days } \\
\text { prior to the covid-19 test } \\
\text { Yes } \\
\text { No } \\
\end{array}$ & $\begin{array}{l}18(1.6 \%) \\
49(4.3 \%)\end{array}$ & $\begin{array}{l}184(16.2 \%) \\
882(77.8 \%)\end{array}$ & 3.970 & 1 & 0.046 \\
\hline
\end{tabular}


Table (2): Multivariate analysis of socio-demographic characteristics and Covid-19 Positivity.

\begin{tabular}{|c|c|c|c|c|c|c|}
\hline \multirow{2}{*}{ Variables } & \multirow{2}{*}{ Wald } & \multirow{2}{*}{ df } & \multirow{2}{*}{ Sig. } & \multirow{2}{*}{$\operatorname{Exp}(B)$} & \multicolumn{2}{|c|}{$95 \% \mathrm{CI}$} \\
\hline & & & & & Lower & Upper \\
\hline \multicolumn{7}{|l|}{ Age } \\
\hline \multicolumn{7}{|l|}{$10-24(r)$} \\
\hline $25-40$ & 11.345 & 1 & 0.001 & 54.923 & 5.338 & 565.064 \\
\hline $41-55$ & 9.363 & 1 & 0.002 & 36.240 & 3.635 & 361.333 \\
\hline $56-65$ & 18.248 & 1 & 0.000 & 188.0 & 17.011 & 2077.717 \\
\hline $66-75$ & 7.616 & 1 & 0.006 & 26.769 & 2.592 & 276.413 \\
\hline $76-95$ & 4.659 & 1 & 0.031 & 14.143 & 1.276 & 156.782 \\
\hline \multicolumn{7}{|l|}{ Sex } \\
\hline $\begin{array}{l}\text { Male } \\
\text { Female(r) }\end{array}$ & 3.135 & 1 & 0.077 & 1.623 & 0.950 & 2.775 \\
\hline \multicolumn{7}{|l|}{ Occupation } \\
\hline Civil Servant & 1.901 & 1 & 0.168 & 1.466 & 0.851 & 2.525 \\
\hline Retired & 1.231 & 1 & 0.997 & 1.423 & 0.613 & 1.883 \\
\hline \multicolumn{7}{|l|}{ Self Employed/Business (r) } \\
\hline $\begin{array}{l}\text { Travelled in the last } 14 \text { days } \\
\text { prior to the covid-19 test }\end{array}$ & & & & & & \\
\hline $\begin{array}{l}\text { Yes } \\
\text { No (r) }\end{array}$ & 3.879 & 1 & 0.049 & 1.761 & 1.003 & 3.092 \\
\hline
\end{tabular}

r: Reference category

Table (3): Bivariate analysis of Co-morbidity, signs and symptoms and Covid-19 Positivity.

\begin{tabular}{|c|c|c|c|c|c|}
\hline \multirow[t]{2}{*}{ Variables } & \multicolumn{2}{|c|}{ No. of persons tested for covid-19 } & $\mathbf{X}^{2}$ & df & \multirow[b]{3}{*}{0.021} \\
\hline & Positive & Negative & \multirow[b]{2}{*}{5.353} & & \\
\hline $\begin{array}{l}\text { Co-morbidity } \\
\text { Yes } \\
\text { No }\end{array}$ & $\begin{array}{l}54(4.8 \%) \\
13(1.1 \%)\end{array}$ & $\begin{array}{l}714(63.0 \%) \\
352(31.1 \%)\end{array}$ & & 1 & \\
\hline $\begin{array}{l}\text { Running Nose } \\
\text { Yes } \\
\text { No }\end{array}$ & $\begin{array}{l}20(1.8 \%) \\
47(4.1 \%)\end{array}$ & $\begin{array}{l}252(22.2 \%) \\
814(71.8 \%)\end{array}$ & 1.333 & 1 & 0.248 \\
\hline $\begin{array}{c}\text { Cough } \\
\text { Yes } \\
\text { No }\end{array}$ & $\begin{array}{c}0(0.0 \%) \\
67(5.9 \%)\end{array}$ & $\begin{array}{l}185(16.3 \%) \\
881(77.8 \%)\end{array}$ & 13.897 & 1 & 0.000 \\
\hline $\begin{array}{l}\text { Shortness of breath } \\
\text { Yes } \\
\text { No } \\
\end{array}$ & $\begin{array}{l}10(0.9 \%) \\
57(5.0 \%) \\
\end{array}$ & $\begin{array}{c}8(0.7 \%) \\
1058(93.4 \%) \\
\end{array}$ & 81.013 & 1 & 0.000 \\
\hline $\begin{array}{l}\text { Vomitting } \\
\text { Yes } \\
\text { No } \\
\end{array}$ & $\begin{array}{l}10(0.9 \%) \\
57(5.0 \%) \\
\end{array}$ & $\begin{array}{c}96(8.5 \%) \\
970(85.6 \%) \\
\end{array}$ & 2.605 & 1 & 0.107 \\
\hline \begin{tabular}{|c|} 
Nausea \\
Yes \\
No \\
\end{tabular} & $\begin{array}{l}30(2.6 \%) \\
37(3.3 \%)\end{array}$ & $\begin{array}{c}79(7.0 \%) \\
987(87.1 \%) \\
\end{array}$ & 101.221 & 1 & 0.000 \\
\hline $\begin{array}{l}\text { Diarrhoea } \\
\text { Yes } \\
\text { No } \\
\end{array}$ & $\begin{array}{l}10(0.9 \%) \\
57(5.0 \%)\end{array}$ & $\begin{array}{c}68(6.0 \%) \\
998(88.1 \%) \\
\end{array}$ & 7.183 & 1 & 0.007 \\
\hline $\begin{array}{l}\text { Other severe life- } \\
\text { threatening illness } \\
\text { Yes } \\
\text { No }\end{array}$ & $\begin{array}{l}44(3.9 \%) \\
23(2.0 \%)\end{array}$ & $\begin{array}{l}552(46.1 \%) \\
544(48.0 \%)\end{array}$ & 7.035 & 1 & 0.008 \\
\hline
\end{tabular}


Table (4): Multivariate analysis of Co-morbidity, Signs and Symptoms and Covid-19 Positivity.

\begin{tabular}{|l|c|c|c|c|c|c|}
\hline \multicolumn{1}{|c|}{ Variables } & Wald & df & Sig. & Exp(B) & \multicolumn{2}{c|}{ 95 CI } \\
\cline { 5 - 7 } & 5.154 & 1 & 0.023 & 2.048 & 1.103 & 3.802 \\
\hline $\begin{array}{l}\text { Co-morbidity } \\
\text { Yes } \\
\text { No (r) }\end{array}$ & 1.176 & 1 & 0.995 & 1.229 & 0.865 & 2.706 \\
\hline $\begin{array}{l}\text { Cough } \\
\text { Yes } \\
\text { No (r) }\end{array}$ & 40.602 & 1 & 0.000 & 23.202 & 8.821 & 61.030 \\
\hline $\begin{array}{l}\text { Shortness of breath } \\
\text { Yes } \\
\text { No (r) }\end{array}$ & 4.675 & 1 & 0.031 & 2.211 & 1.077 & 4.540 \\
\hline $\begin{array}{l}\text { Vomiting } \\
\text { Yes } \\
\text { No (r) }\end{array}$ & 72.422 & 1 & 0.000 & 10.130 & 5.943 & 17.267 \\
\hline $\begin{array}{l}\text { Nausea } \\
\text { Yes } \\
\text { No (r) }\end{array}$ & 6.713 & 1 & 0.010 & 2.575 & 1.259 & 5.266 \\
\hline $\begin{array}{l}\text { Diarrhoea } \\
\begin{array}{l}\text { Yes } \\
\text { No (r) }\end{array}\end{array}$ & 6.805 & 1 & 0.009 & 1.994 & 1.187 & 3.348 \\
\hline $\begin{array}{l}\text { Other severe life- } \\
\text { threatening illness } \\
\text { Yes } \\
\text { No (r) }\end{array}$ & & & & & \\
\hline
\end{tabular}

CI: Confidence Interval, r: Reference Category

\section{DISCUSSION}

The study was a retrospective study carried out in Ndokwa-West Local Government Area of Delta State Southern Nigeria. According to the finding of the study, age was a significant predictor of Covid-19 positivity. Patients within ages 25-95 years were more likely to show positivity of Covid-19 than patients with a lower age range. Although Covid-19 affects all age groups, patients age has been reported as one of the critical factors predicting clinical outcomes of affected patients [12-14].In addition to predicting infected patients clinical outcomes, age is also an independent demographic factor predicting Covid-19 positivity. This was corroborated by a national study in Nigeria where older age was independently associated with Covid-19 positivity [7].

Furthermore, being male has been reported to be a significant risk factor for contracting Covid-19 [15-16]. This was substantiated by the finding of the current study where male patients were more likely to be diagnosed with Covid-19 positivity than females. This was also substantiated by the results of previous studies in the United Kingdom and Nigeria, where male sex was independently associated with Covid-19 positivity $[\mathbf{7 , 1 7 ]}$. This observed sex difference could be attributed to a combination of genetic, physiological and socio-cultural factors. Two possible explanations are the broader distribution of SARS- CoV-2 cellular receptor, ACE-2, in men compared with those of women [18].Also, the cultural perspective in Nigeria of males being 'bread winners' in their respective families and are therefore more likely to go out, travel and interact with their close community than females, consequently increasing their chances of exposure to the virus. Besides, patients who travelled 14 days before the Covid-19 test were more likely to show Covid-19 positivity than patients who had not travelled. This finding differed from that of the study in Nigeria, where lower odds for infection were observed for both local and international travelers [7].Travelling both local and internationally was more likely to expose travellers to Covid-19. Although, various measures such as the enforcement of physical distancing for local travels, provision of Covid19 information, National Centre for Disease Control contact details, use of face masks and routine hand hygiene for international travellers were put in place by the Nigerian Government. The likelihood of exposure to Covid-19 for travellers was higher than non-travellers.

Common clinical manifestations associated with Covid-19 infection were fever, cough, 
breathlessness, vomiting and diarrhoea $[5,19]$. In addition, co-morbidities such as hypertension, diabetes, cardiovascular disease, chronic lung disease and cancer have been associated with poor patient clinical outcomes and Covid-19 related death [20,21].Multivariate analysis shows that having co-morbidity, other severe lifethreatening illnesses, presentation with shortness of breath, vomiting, nausea, and diarrhoea were significant predictors of Covid-19 positivity. This finding was similar to the national study finding in Nigeria, where presenting symptoms such as cough, fever, loss of smell and taste were independently associated with Covid-19 positivity [7]. A limitation for the study is limiting the sample size to patients with complete socio-demographic data, consequently reducing the sample size.

\section{CONCLUSION}

The study highlighted possible factors independently associated with Covid-19 positivity in the low resource setting like the study area, which was similar to that of the national level. Therefore, this finding should guide health workers and policymakers at the local and national levels in implementing best practices for Covid-19 testing and care.

\section{Recommendations:}

1. Continuous research both locally and nationally on the various independent factors influencing Covid-19 positivity.

2. The various highlighted local factors should be incorporated into Covid-19 care and prevention in the study area and beyond.

3. Specifically, age is a very pertinent independent factor which should be focused on in protecting the aged and elderly especially those with co-morbid and other life threatening conditions from Covid-19 related morbidity and mortality..

Funding: None.

Conflict of interest: None.

Ethical Considerations: Approval for the study was obtained from the Department of Public and Community Health, Novena University Ogume Delta State and the head of the Disease Surveillance and Notification office of the
Ndokwa-West Local Government Area of Delta State.

\section{Research Highlights:}

-The study showed the prevalence of Covid-19 in Ndokwa District of Delta State

-The study highlighted independent factors predicting Covid-19 positivity in Ndokwa District of Delta State

-The study was unique because it presented local data and addressed the paucity of studies on independent factors predicting Covid-19 positivity in Delta State

\section{REFERENCES}

1. World Health Organisation. Coronavirus disease (COVID-19) Situation Report- 122. Available at: https://reliefweb.int/report/world/coronavirusdisease-2019-covid-19-situation-report-122-21may-2020. Accessed on 20 October 2020.

2. Centre for Disease Control. Novel Coronavirus, Wuhan, China. CDC 2019. Available at https://www.cdc.gov/coronavirus/2019ncov/about/index.html.January 26, 2020; Accessed on 27 January 2020.

3. World Health Organisation. WHO Coronavirus (COVID-19) Dashboard. Available at: https://covid19.who.int/. Accessed on 14 October 2021.

4. Nigerian Centre for Disease Control. NCDC Coronavirus (COVID-19) Dashboard. Available at: https://covid19.ncdc.gov.ng/report/. Accessed on 14 October 2021.

5. Fu L, Wang B, Yuan T, Chen X, Ao Y, Fitzpatrick $\mathrm{T}$, et al. Clinical characteristics of coronavirus disease 2019 (COVID-19) in China: a systematic review and meta-analysis.J Infect2020; 80: 656665.

6. Bowale A, Abayomi A, Idris J, Omilabu S, Abdus-Salam I, Adebayo B, et al. Clinical presentation, case management and outcomes for the first 32 COVID-19 patients in Nigeria.Pan Afr Med J2020; 35(Suppl 2): 24.

7. Elimian KO, Ochu CL, Ebhodaghe B, Myles P, Crawford EE, Igumbor $\mathrm{E}$, et al. Patient characteristics associated with COVID-19 positivity and fatality in Nigeria: retrospective cohort study. BMJ Open 2020; 10:e044079. doi:10.1136/bmjopen-2020-044079.

8. Helmholtz Centre for Infection Research. SORMAS: the real-time software for outbreak and epidemic surveillance, 2019. Available: https://sormasorg.helmholtz-

hzi.de/About_SORMAS.html [Accessed 14 October 2021]. 
9. Nigeria Centre for Disease Control. National interim guidelines for clinical management of COVID-19, version 2, may 2020. Abuja. Available:

https://ncdc.gov.ng/themes/common/docs/protocol s/177_1584210847.pdf [Accessed 10th October, 2020].

10. World Health Organization. Laboratory testing for coronavirus disease (COVID-19) in suspected human cases: interim guidance, 19 March 2020. WHO. Available: https://www.who.int/publicationsdetail/laboratory-testing-for-2019-novelcoronavirus-in-suspected-human-cases-20200117 [Accessed 10 October 2021].

11. Nigeria Centre for Disease Control. Case definitions for coronavirus disease. Abuja, 2020. Available:

https://covid19.ncdc.gov.ng/media/files/Case_Defi nition.pdf [Accessed 9 October, 2020].

12. Bhopal R. COVID-19 worldwide: we need precise data by age group and sex urgently. BMJ 2020; 369: 1366

13. Lauc G, Sinclair D. Biomarkers of biological age as predictors of COVID-19 disease severityAging (Albany NY), 2020; 12 (8): 6490-6491.

14. Mahase E. COVID-19: death rate is $0.66 \%$ and increases with age, study estimates. BMJ 2020; 369:1327.

15. Zhang J, Wang X, Jia X, Li J, Hu K, Chen G, et al. Risk factors for disease severity, unimprovement, and mortality in COVID-19 patients in Wuhan, China. Clin Microbiol Infect 2020; 26:767-72.
16. Wang D, Hu B, Hu C, Zhu F, Liu X, Zhang J, et al. Clinical characteristics of 138 hospitalized patients with 2019 novel coronavirus-infected pneumonia in Wuhan, China. JAMA 2020; 323:1061-1069.

17. de Lusignan S, Dorward J, Correa A, Jones $\mathrm{N}$, Akinyemi O, Amirthalingam G, et al. Risk factors for SARS-CoV-2 among patients in the Oxford Royal College of general practitioners research and surveillance centre primary care network: a cross-sectional study. Lancet Infect Dis 2020; 20:1034-42.

18. Patel SK, Velkoska E, Burrell LM. Emerging markers in cardiovascular disease: where does angiotensin-converting enzyme 2 fit in? Clin Exp Pharmacol Physiol 2013; 40:551-559.

19. Aggarwal S, Garcia-Telles N, Aggarwal G, Lavie C, Lippi G, Henry BM. Clinical features, laboratory characteristics, and outcomes of patients hospitalized with coronavirus disease 2019(COVID-19): early report from the United States. Diagnosis 2020; 7: 91-96.

20. Yang J, Zheng Y, Gou X, Pu K, Chen Z, Guo Q, et al. Prevalence of co-morbidities and its effects in coronavirus disease 2019 patients: a systematic review and meta-analysis. Int J Infect Dis 2020; 94:91-5.

21. Chen T, Wu D, Chen H, Yan W, Yang D, Chen G, et al. Clinical characteristics of 113 deceased patients with coronavirus disease 2019: retrospective study. BMJ 2020; 368:m1091. 